\title{
ГІБРИДНІ ВІЙНИ ХХІ СТОЛІТТЯ: НОВІ ВИКЛИКИ ДЛЯ МЕДІАПРОСТОРУ
}

\author{
Оксана Левантович \\ Украӥнський Католицький Університет, \\ вул. І. Свєниіиького, 17, 79000, Львів, Украӥна \\ e-mail: oksana.levantovych@gmail.com \\ https://orcid.org/0000-0002-4263-8542
}

У статті розкрито явище гібридної війни, в якій в умовах XXI ст. успішно використовують нові інформаційно-маніпулятивні засоби, зокрема, пропаганду через 3МI, 3 метою дискредитувати суперника. Як наслідок, головне протистояння відбувається не на фізичному полі бою, а в головах людей.

Ключові слова: інформаційне суспільство, пропаганда, маніпуляція свідомістю, російсько-українська війна.

Сьогодні ледь не 3 кожного ЗМI, соціальних мереж чи будь-якого іншого майданчика лунає твердження, мовляв, ми живемо у світі пост-правди, де межі між правдою та вигадкою розмиті і це створює відверту загрозу для людства у XXI ст. Втім у свої найновішій праці «21 урок для 21 століття» Ювал Ной Харарі слушно зауважив, що «насправді люди завжди жили в епоху пост-правди. Homo sapiens - це вид пост-правди, чия сила залежить від створення вигадок і вірування в них. Від Кам'яної доби самопідтримувані міфи слугували для об'єднання людських колективів» [1, с. 290]. Тобто схильність людей використовувати неправдиву інформацію в своїх цілях $є$ чимось абсолютно природним для людини, яка живе у спільноті з іншими людьми, i не дивно, що цей принцип у майбутньому поширюється на стосунки між країнами.

Те, 3 цим зіштовхується світ сьогодні, - це, радше, абсолютно новий рівень маніпулятивних технологій для пропагування вигідної інформації, стереотипів чи міфів, які стають елементом гібридного протистояння в умовах війни, яке, між, іншим не обмежується інформаційними впливами: «Сьогоднішня гібридна війна розгорнута на всіх можливих напрямках, це не лише інформаційна війна. Це однозначно війна економічна, репутаційна, смислова, людська... На неї повинні працювати всі, хто має вплив на населення: актори, співаки, письменники, режисери. Воєнні дії створюють лише фон для більш масштабної війни в людському розумінні» [1, с. 264].

Сьогодні перед нами протистояння, для яких перемога на полі бою $є$ лише однією з бажаних, але точно не найголовніших перемог. Внаслідок стрімкої еволюції

(С Левантович О., 2019

Наукове рецензування і рекомендація до друку - доц. Хоменко Т. М. 
воєн, одні механізми впливу змінюють інші, і час, за який відбуваються ці зміни, стає щораз коротшим. Війни, які колись були відкритим та теоретично зрозумілим явищем, сьогодні перетворилися на незрозумілі офіційно неоголошені дії - «війни-мутанти», «гібридні війни», які важко окреслити певними рамками. У широкому значенні «гібридна війна» - це прагнення однієї держави нав’язати іншій свою політичну волю через комплекс заходів політичного, економічного, інформаційного характеру і без оголошення війни, відповідно до норм міжнародного права» [3].

Зрозуміло, що «гібридна війна» - це не винахід сьогодення. Адже схожі комбінації інформаційної, психологічної, економічної та військової боротьби використовувалися і раніше. Але в сучасних конфліктах набагато більша кількість факторів, від яких залежить успіх, в рази сильніша і пропаганда через ЗМІ. «Гібридну війну досить часто тлумачать не як щось нове, оскільки більшість їі складових траплялися й раніше. Новим стало об'єднання цих складових у єдине ціле, а також додаткова особлива роль інформаційного компоненту, який на різних рівнях забезпечує функціонування і створює умови для того, щоб справедливість війни визнало власне населення, без чого не буває сучасних воєн» [4]. Так би мовити «справедливість» стає ключовим фактором, адже так чи інакше перемогу здобувають ті, що які виглядають справедливими у очах своїх. Прикладів в історії безліч, один із яскравих - війна в Іраку/Афганістані. Коли вона стала аж надто затяжною, влада вирішила проводити різноманітні конференції на цю тему, метою яких було пояснити населенню, що правда на їх стороні. Зрозуміло, що тільки справедливу, благородну війну може підтримати більшість. Подібно і з квазіреферендумом у Криму, його метою було отримання схвалення від суспільства встановлення російської влади на півострові $[2$, c. 125$]$.

Сучасні «гібридні війни» із тривимірного простору (суходіл, море, повітря) поступово перейшли у четвертий вимір - психіку воюючих сторін. Більше того, вони, як правило, починаються зненацька. Тому військовим вкрай важко вчитися протистояти неочікуваними загрозам, адже час працює проти тих, хто орієнтується на старі моделі війни. Базові знання класичних воєн потрібні, але сьогодні одні вони не допоможуть дати гідну інформаційну відсіч, адже її доведеться вводити на різних рівнях.

Так чи інакше світова карта сьогодення переповнена гібридними протистояннями, мова і про невеликі конфлікти, і про масштабні війни, з'являється потреба розробляти асиметричну, гібридну відповідь. Система безпеки, яку розробило міжнародне право після 1945 року, сьогодні не може відповісти на загрозу нового виклику, а провідні світові організації, як, скажімо, ООН, будують свою роботу, керуючись доктринами, прийнятими після Другої світової війни. Відповідно, сучасні типи конфліктів потребують зовсім іншого правового трактування. Звісно, це зробити не так вже й легко, адже важко визначити місце «гібридної війни» у міжнародному праві, оскільки досі немає чітких рамок, які окреслювали б поняття «гібридної війни».

Френк Г. Хоффман, колишній офіцер морської піхоти, науковий співробітник міністерства оборони США, наголошував, що у майбутньому «конфлікти будуть мультимодальними (тобто такими, що ведуться різними способами) та багатоваріантними, що не входять в межі простої конструкції ведення збройного конфлікту чи війни. А майбутні загрози можуть більшою мірою бути охарактеризованими як гібридне співвідношення традиційних та нерегулярних стратегій і тактик, це децен- 
тралізоване планування та виконання, участь недержавних акторів 3 використанням одночасно простих та складних технологій» [5].

Тобто «гібридна війна», яка до певної міри є логічним наслідком глобалізації, включає у себе низку складних операцій, що розмивають традиційні уявлення про війну. На думку колишнього секретаря РНБО Володимира Горбуліна, «поєднання традиційних і гібридних методів уже тепер є характерною рисою будь-якого збройного конфлікту. При цьому, якщо другі можна використовувати і без відкритого застосування військової сили, то класичні бойові дії без гібридних - уже ні» [6].

Ще Сунь Цзи зауважував: «як вода не має постійної форми, так вода не має постійних умов» [3, с. 14]. Війна у багатьох моментах стає метафізичною, ніби скрізь, але водночас ніде, вона дуже непередбачувана і непостійна, тоді як людство звикло функціонувати за певними шаблонами. В умовах нового протистояння жодних шаблонів не існує, адже гібридна агресія вимагає і гібридної оборони, а не застосування класичних відповідей на сучасні запитання. Слід перестати вважати, що війна це коли воюють, а мир - коли не воюють, адже можна перебувати в стані війни без воєнних дій. Річ у тім, що сучасна форма війни - це змова, заколот, синтез різних методів: звичних і незвичних, відвертих і прихованих, регулярних і нерегулярних, які повинні ефективно впливати на маси.

Успіх у «гібридній війні» буде на боці того, хто вміє працювати з масовою свідомістю. Сторона, що атакує, повинна доводити справедливість своїх дій і власному народові, і народу, на який націлена атака. А для атакованої сторони доволі важко давати відповідь такій неоголошеній війні, тому передовсім потрібно будувати міцну та новітню пропагандистську підтримку. «По-перше, є потреба постійних інтерпретацій і реінтерпретацій, оскільки під час «гібридної війни» відбувається доволі швидка зміна подій. По-друге, реальні події відрізняються від пропагандистських картинок, котрі потребують постійного посилення пропагандистського супроводу. По-третє, в «гібридній війні» багато чого потрібно приховати, підсилити, наприклад, є чіткий поділ на свій/чужий» [7].

Довго втримувати інтенсивність гібридного протистояння важко, і рано чи пізно воно переростає у перманентний стан. Це вигідно для посттоталітарних країн, зокрема, для Росії, яка веде неоголошену «гібридну війну» проти України. Річ у тім, що при авторитарних режимах безперервна мобілізація населення працює на користь влади, а не надто інтенсивні воєнні дії знесилюють, руйнують країну, проти якої ведеться «гібридна війна» зсередини.

Отже, яскравим прикладом сучасної «гібридної війни» $є$ російсько-українська війна на Сході України, що розпочалася у 2014 році і триває досі, перерісши у перманентний стан. Спершу події на Євромайдані, початок Революції Гідності, далі - анексія Криму і розвиток воєнних дій на Донбасі і створення лжеутворень так званих «ДНР» та «ЛНР». Мета Росії очевидна: підірвати структуру управління України, інфраструктуру, посіяти хаос та дестабілізацію. Але все розпочалось не 3 класичного плану прямих воєнних дій, а з інформаційного протистояння, пропаганди через 3МІ. У випадку з Кримом та Донбасом, на думку британських експертів, спершу відбулись такі інформаційні втручання з боку Росії: «створення у «російських співвітчизників» т. зв. м'якої лояльності до Росії через акцентування культурних, мовних та ідеологічних зв'язків та поширення страху, що їхні уряди почнуть працювати проти них?» [4]. 
Для характеристики та сучасного протистояння на Сході України, окрім «гібридної війни», використовують також інші поняття, такі як «неконвенційна війна», «нерегулярна війна», «змішана війна». Яким би не було означення, у всіх випадках воно вказує на певну розмитість, нечіткість військового конфлікту та залучення до нього невійськових засобів.

Сучасні технології перебувають на такому високому рівні, що це дає змогу уникати гострої фази. На думку українського політолога Костя Бондаренка, російсько-українська війна на $80 \%$ складається з інформаційних і економічних дій і лише $20 \%$ - 3 бойових, яких може взагалі і не бути. «Україна, насправді, не $є$ учасником війни. Вона $€$ полем битви, на жаль, а українці $є$ таким собі «гарматним м'ясом» у цій «гібридній війні». Війна ведеться між великими гравцями, геополітичними гравцями - між Заходом і Росією. Що стосується України - вона, як і Сирія та інші арабські держави, є полігоном. На жаль, українці цього не розуміють» [8].

Україна вперше зіштовхнулася з війною, яку дуже важко розпізнати, через специфіку ведення. А воювати з «невійною» насправді нелегко, тим паче що на початковому етапі не було воєнних дій, а те, що відбувалося довкола, можна охарактеризувати як маніпулювання чинниками довіри та недовіри. Постає питання у відсутності реального захисту інформаційного (новини) та віртуального (література, культура, ідеологія) просторів країни. Г. Почепцов наголошує, що «за роки незалежності власного конкурентного продукту так і не було створено, адже використання чужого продукту - значно полегшений і дешевший спосіб їх заповнення. Кошти потрібно вкладати не лише в прямі воєнні завдання, але й у ті, що опосередковано впливають на них» $[9$, с. 464].

Відтак, в умовах гібридної російсько-української війни формується новітня російська пропаганда, інструментом якої стають ЗМІ. Отож, медіа і пропаганда стають тотожними. Попри те, що військовий складник об'єктивно залишається головним, важливість інформації невпинно зростає. Про масштаби інформаційної війни Росії проти України влучно сказав головнокомандувач об’єднаних Збройних сил НАТО в Європі Ф. Брідлав: «Це найбільш дивовижний інформаційний бліцкриг, який ми коли-небудь бачили в історії інформаційних воєн». [10]. Таке порівняння справді влучне, адже російські медіа розгорнули свою пропагандистську діяльність одразу на декількох фронтах: серед населення у зоні конфлікту на Сході, серед населення країни, не охопленої конфліктом, але проти якої здійснюється агресія, серед громадян країни агресора, а також серед міжнародного співтовариства.

У випадку російсько-української війни маємо розуміти, що йдеться не лише про ворожу пропаганду, а про так звану «війну смислів» з метою створення образів, яких насправді не існує, наприклад, «фашисти в Києві», «звірства каральних батальйонів», «розіп’яті хлопчики»... У статті «Україна і початок нелінійної війни» Майкл Вайс і Пітер Померанцев наголошують: «У Росії та на сході України, де російське телебачення користується популярністю, кремлівським політтехнологам вдалося створити паралельну реальність, у якій «фашисти» захопили владу в Києві, етнічні росіяни в східній Україні перебувають у смертельній небезпеці, а ЦРУ веде війну з Москвою» [11].

Такі вигадки майстерно пропагували російські медіа, не відчувши достатнього спротиву з боку українських медіа, тим паче, перше, що зробили ополченці на Схо- 
ді - це відключили українські телеканали і підключали російські з метою створення контрольованого інформаційного простору.

Далі розпочалось активне просування пропаганди, i для іï результативності Росія використовує широкий спектр методів гібридної війни: «перекручування, пересмикування фактів та дискурсів; використання особи колишнього президента Віктора Януковича для тиску та потенційного піддання сумнівам легітимності нинішньої влади; викривлення фактів українсько-російської історії; створення видимості відсутності агресії; умисне створення зростання панічних настроїв, намагання створити проросійську коаліцію на Заході, лобіювання проросійських інтересів; інформаційна кампанія спрямована на формування позитивного образу Росії в Свропі» [12].

Один із фронтів інформаційної війни знаходиться, звісно ж, в самій Росії, більшість населення сліпо підтримує імперські амбіції Росії і вірить усьому, що лунає 3 телеекранів. У певному сенсі справді можна сказати, що росіяни першими впали під тиском власного телебачення. Втім, не менш важливий для «гібридної війни» зовнішній фронт, на який поширює пропагандистські меседжі російська пропаганда. I тут мова не лише про Україну, стратегічним напрямком є Свропа та світ: «масштаби діяльності «фондів», «культурних товариств», «аналітичних центрів» і просто «експертів» проросійської спрямованості в Свропі, а також діяльність каналу «RT» справді значні. Однак навіть тут загальна концепція «гібридної війни» «по-російськи» дається взнаки: частину таких експертів просто вигадують, а від їхнього імені публікують потрібні коментарі та висновки» [10].

Але чому Росія вигадує експертів, пропагує очевидну неправду, невже вона не розуміс, що світ бачить цю відверту брехню? Річ у тім, що сьогодні вже не відбувається боротьба за правду, не важливо на чиєму вона боці, важливо лише - у чиїх руках кермо. Мета Росії - показати, що правда не існує, що реальність $є$ дуже гнучкою і абсурдною. Саме така ідея і лягає в основу новітньої пропаганди у контексті «гібридної війни» і чинить велику загрозу для Заходу.

Європейські медіа часто не розуміють, що іноді самі грають на користь Кремля, використовуючи неперевірені факти: «кореспонденти німецької газети «Der Tagesspiegel» писали про чеченських бойовиків у проросійських батальйонах в Україні, які «воюють на боці сепаратистів, за повідомленнями західних медіа, і на боці українських збройних сил, за заявами Москви». У статті повторювалися неперевірені заяви російських посадовців про зв'язок української міліції з чеченськими ватажками. У відповідь на цю статтю кореспондент журналу «Focus Magazine» Боріс Райтшустер саркастично заявив: «Немає нічого поганого в тому, щоб повторювати кремлівську пропаганду. Але слід зазначати, що це пропаганда» [11].

Такі помилки, яких припускаються західні журналісти, можуть стати фатальними і мова навіть не про перемогу чи поразку суто в інформаційній війні, а про геополітичну долю Європи. Доречними у цьому контексті будуть слова президента Литви Д. Грібаускайте, котра зауважила, що «Україна зараз бореться заради всього світу, заради всіх нас. Якщо терористичну державу, яка веде відкриту агресію проти свого сусіда, не зупинити, вона пошириться на Європу і далі» [10]. Це припущення не можна ігнорувати, адже «гібридна війна» - це метод агресивного вирішення Росією власних геополітичних цілей, які, звісно ж, не обмежуються Україною.

Існує хибна думка про те, що Росія за своїми методами пропаганди залишилась у далеких радянських часах. Історик Тімоті Снайдер спростовує таку тезу, на- 
голошуючи, що «подобається нам чи ні, але вони (російська влада) найкращі пропагандисти у світі. Психологічні методи, які вони застосовують, впливають на розум. Вони точно у XXI столітті, радше вони змушують нас виглядати як із XIX століття» [13]. Тобто насправді російська пропаганда є постмодерною, байдужою до протиріч, і може дозволити собі відверту брехню, наприклад, назвати українців фашистами, тобто брати будь-яке явище $з$ історії та інтерпретувати його по-своєму. Т. Снайдер зіставляє використання фактів історії Свропою та Росією: «Наприклад, ми вивчаємо уроки Холокосту, намагаємось пересвідчитись, що таке більше не повториться. Це дуже повільний процес. Свразійці дивляться на історію як на контейнер цікавих речей, які ви можете вихоплювати як завгодно - і ми ніколи не передбачимо, що вони вихоплять наступним» [13].

Таке ситуативне трактування історії та створення на її основі «паралельної реальності» стають сьогодні ознаками новітньої «гібридної війни». Українській владі та суспільству залишається ледь не утопічний спосіб вирішення проблеми російської агресії та пропаганди: з одного боку, не піддаватися на нав’язування зовнішньої, деструктивної політики і при цьому вести активні воєнні та інформаційно-пропагандистські дії, котрі б виснажували противника, а з іншого боку, забезпечити домінування української вдали в окупованих регіонах. Звісно, це доволі ідеалістичний сценарій, адже, де-факто, контролювати територію, охоплену противником, сьогодні здається нереальним. Втім вкрай важливо сьогодні - попри все боротися за чистий інформаційний простір і велика відповідальність, у цьому контексті, лежить саме на 3MI.

Висновки. Ми свідомі того, що у XXI столітті пропаганда знайшла універсальне втілення у системі нового типу протистояння - «гібридних воєн». Війна, яка може існувати без прямих воєнних дій, яка синтезує усі можливі класичні та новітні методи боротьби, яка, радше, обирає перманентний стан, аби якомога більше виснажити ворога і на тлі якої будується нова пропагандистська медіареальність, стає війною нового тисячоліття. Яскравим прикладом втілення пропаганди «гібридної війни» $є$ інформаційне протистояння у сучасній російсько-українській війні. Завдання Росії у цій боротьбі - продемонструвати світові, що існує нова реальність, в якій правда доволі відносне поняття.

\section{REFERENCES}

1. Харарі Ювал Ной. 21 урок для 21 століття. К. : BookChef, 2018. С. 290-264.

2. Почепцов Г. Смисли і війни: Україна і Росія в інформаційній і смисловій війнах. К.: Видавничий дім «Києво-Могилянська академія», 2016. С. 125.

3. Магда Є. Гібридна війна: вижити і перемогти / Є. Магда. Х. : Віват. 304 с.

4. Почепцов Г. Г. 3 історії поняття гібридної війни в США і Росії [Електронний ресурс] / Г. Г. Почепцов // Media Sapiens. - Режим доступу: http://osvita.mediasapiens. ua/trends/1411978127/z_istorii_ponyattya_gibridnoi_viyni_v_ssha_i_rosii/

5. Власюк В. В., Карман Я. В. Деякі основи поняття «Гібридна війна» в міжнародному праві [Електронний ресурс] / В.В. Власюк, Я.В. Карман. - Режим доступу: http://lcslaw.knu.ua/index.php/item/207-deyaki-osnovy-ponyattya- 
6. Горбулін В. Гібридна війна: все тільки починається [Електронний ресурс] / В. Горбулін // Дзеркало тижня. - Режим доступу: http://gazeta.dt.ua/internal/gibridnaviyna-vse-tilki-pochinayetsya-_.html

7. Почепцов Г. Г. Гібридна війна: інформаційна складова [Електронний ресурс] / Г.Г. Почепцов // Media Sapiens. - Режим доступу: http://osvita.mediasapiens.ua/ trends/1411978127/gibridna viyna informatsiyna skladova/

8. Гібридна війна в Україні: думки експертів [Ёлектронний ресурс] / Polonews. Режим доступу: http://polonews.in.ua/aktualnosci/polityka/gibridna-vijna-v-ukrajinidumki-ekspertiv.html

9. Почепцов Г. Г. Сучасні інформаційні війни / Г. Г. Почепцов. К. : Вид. дім «Києво-Могилянська академія», 2015. 497 c. https://www.questia.com/read/14143465/achronology-and-glossary-of-propaganda-in-the-united

10. Горбулін В. «Гібридна війна» як ключовий інструмент російської геостратегії реваншу [Електронний ресурс] / В. Горбулін // Дзеркало тижня. - Режим доступу: http:/gazeta.dt.ua/internal/gibridna-viyna-yak-klyuchoviy-instrument-rosiyskoyigeostrategiyi-revanshu-_.html

11. Вайс М., Померанцев П. Україна і початок «нелінійної» війни [Електронний ресурс] / М. Вайс, П. Померанцев // Критика. - Режим доступу: http://krytyka.com/ ua/articles/ukrayina-i-pochatok-neliniynoyi-viyny

12. Магда $€$. Виклики гібридної війни: інформаційний вимір [Електронний ресурс] / Є. Магда. - Режим доступу: file:///C:/Users/home/Desktop/Nzizvru_2014_5_29\%20 (1).pdf

13. Тімоті Снайдер: Російській пропаганді байдуже до протиріч - історію XX століття вона презентує у постмодерний спосіб [Електронний ресурс]. - Режим доступу: http://osvita.mediasapiens.ua/ethics/manipulation/timoti_snayder_rosiyskiy propagandi_bayduzhe_do_protirich_istoriyu_khkh_stolittya_vona_prezentue_u_postmoderniy_sposib/ 


\title{
HYBRID WARFARE IN THE 21 ${ }^{\mathrm{ST}}$ CENTURY: THE CHALLENGES IN THE AREA OF SOCIAL INFORMATION MEDIA
}

\author{
Oksana Levantovych \\ Ukrainian Catholic University, \\ I. Svientsitskoho Street, 17, 79011, Lviv, Ukraine \\ e-mail: oksana.levantovych@gmail.com \\ https://orcid.org/0000-0002-4263-8542
}

The article dwells on the phenomenon of hybrid warfare in the 21st century, the one that utilizes all the information-manipulative means simultaneously. This primary feature makes it different from the wars of the past centuries. Consequently, one should understand that the contexts of hybrid confrontations pose a challenge for media space as well. This article aims to highlight some of them. First. People have always lived in a post-truth era. It is only a matter of technology that makes the difference nowadays. Thus the human tendency to exploit fake information is something absolutely natural for one living within a society. However, the 21st century provides an entirely new level of manipulative technologies.

Second. Hybrid wars are waged on all fronts. Today we face a confrontation in which victory on the battlefield is just one of the desired outcomes rather than the top priority. Hybrid warfare also implies economic, reputational, semantic, and human aspects... Anyone with the means of influencing the population ought to be engaged: actors, singers, writers, directors, etc. Nowadays, investments are made both in direct military tasks and those affecting them indirectly.

Third. A hybrid war declares itself above board, creating an image of a just war, the one acknowledged by the local population. This so-called «justice» serves as a key factor because, at the end of the day, those who look just in the eyes of their own people emerge victorious.

Fourth. Modern hybrid warfare has gradually outgrown its three dimensions (land, sea, air) and spread to the fourth one - the psyche of the belligerents. Due to the influx of propaganda, an average person is easily exposed to apt and usually untrue information. Nowadays, social networks have a particularly potent impact as it is easy to end up in an information bubble or in a vacuum, and thus to become even more susceptible to false messenger bots or corrupt media. Fifth. People ceased to struggle for the truth, regardless of the side it is on. The only thing that matters nowadays is whose hands are steering the wheel. Russia's goal in the modern RussianUkrainian war, so to speak, is to demonstrate that there is no truth as such, proving the reality utterly flexible and absurd. This very idea lays the basis for modern propaganda in the context of hybrid warfare.

Key words: information society, propaganda, manipulation of consciousness, RussianUkrainian war. 